\title{
EFEKTIVITAS KEPEMIMPINAN KEPALA SEKOLAH DALAM MENINGKATKAN KINERJA GURU
}

\author{
Enas $^{1}$ \\ ${ }^{1}$ Program Studi Manajemen Pascasarjana Universitas Galuh Ciamis \\ email: enas.email@gmail.com
}

\author{
Article History : \\ Received 15 August 2018 \\ Recieved in revished form \\ 28 September 2018 \\ Acepted 20 October 2018 \\ Available offline 29 October 2018 \\ Available online 29 October 2018
}

Language Transcript :

Indonesia (id)

Key Words :

Efektivitas

Kepemimpinan Kepala Sekolah

Kinerja Guru

\begin{abstract}
Tujuan penelitian adalah untuk menganalisis dan mendeskripsikan tentang:1) Kepemimpinan kepala sekolah ditinjau dari kompetensi kepribadian dalam meningkatkan kinerja guru. 2) Kepemimpinan kepala sekolah ditinjau dari kompetensi manajerial dalam meningkatkan kinerja guru. 3) Kepemimpinan kepala sekolah ditinjau dari kompetensi kewirausahaan dalam meningkatkan kinerja guru. 4) Kepemimpinan kepala sekolah ditinjau dari kompetensi supervisi dalam meningkatkan kinerja guru. 5) Kepemimpinan kepala sekolah ditinjau dari kompetensi sosial dalam meningkatkan kinerja guru. Metode penelitian yang digunakan dalam penyusunan penelitian ini adalah deskriptif dengan pendekatan kualitatif. Informan pada penelitian ini meliputi kepala sekolah, pengawas, dan guru. Hasil penelitian menunjukkan bahwa: 1) Kepemimpinan kepala sekolah ditinjau dari kompetensi kepribadian pada umumnya berkriteria efektif sehingga dapat meningkatkan kinerja guru. 2) Kepemimpinan kepala sekolah ditinjau dari kompetensi manajerial pada umumnya berada pada kriteria efektif sehingga dapat meningkatkan kinerja guru. 3) Kepemimpinan kepala sekolah ditinjau dari kompetensi kewirausahaan pada umumnya berada pada kriteria efektif sehingga dapat meningkatkan kinerja guru. 4) Kepemimpinan kepala sekolah ditinjau dari kompetensi supervisi pada umumnya berada pada kriteria efektif sehingga dapat meningkatkan kinerja guru. 5) Kepemimpinan kepala sekolah ditinjau dari kompetensi sosial pada umumnya berada pada kriteria efektif sehingga dapat meningkatkan kinerja guru.
\end{abstract}

\section{PENDAHULUAN}

Pentingnya pendidikan yang dapat memberikanharapan dan kemungkinan yang lebih baik di masa mendatang, telah mendorongberbagai upaya dan perhatian seluruh lapisan masyarakat terhadap setiap deraplangkah dan perkembangan dunia pendidikan. Pendidikan sebagai salah satuupaya dalam rangka meningkatkan kualitas hidup manusia, pada intinya bertujuanuntuk memanusiakan manusia, mendewasakan, merubah perilaku, sertameningkatkan kualitas menjadi lebih baik.Pada kenyataannya pendidikan bukanlah suatu upaya yang sederhana,melainkan suatu kegiatan yang dinamis dan penuh tantangan. Pendidikan akanselalu berubah seiring dengan perubahan jaman. Setiap saat pendidikan selalumenjadi fokus perhatian dan bahkan tidak jarang menjadi sasaran ketidakpuasan,karena pendidikan menyangkut kepentingan semua orang, bukan hanyamenyangkut investasi dan kondisi kehidupan di masa yang akan 
datang,melainkan juga menyangkut kondisi dan suasana kehidupan saat ini. Itulahsebabnya pendidikan senantiasa memerlukan upaya perbaikan dan peningkatansejalan dengan semakin tingginya kebutuhan dan tuntutan kehidupan masyarakat.

Sampai satu dasawarsa terakhir penghujung abad ke- 20, dunia pendidikanbelum sepenuhnya dapat memenuhi harapan masyarakat. Fenomena ituditandai dengan rendahnya mutu lulusan, penyelesaian masalah pendidikan yangtidak tuntas atau cenderung tambal sulam, bahkan lebih berorientasi proyek.Akibatnya seringkali hasil pendidikan mengecewakan masyarakat. Mereka terusmempertanyakan relevansi pendidikan dengan kebutuhan masyarakat dalamdinamika kehidupan ekonomi, politik, sosial, budaya. Kualitas lulusan pendidikankurang sesuai dengan kebutuhan pasar tenaga kerja dan pembangunan, baikindustri, perbankan, telekomunikasi, maupun pasaran tenaga kerja sektor lainnyayang cenderung menggugat eksistensi sekolah. Bahkan sumber daya manusia(SDM) yang disiapkan melalui pendidikan sebagai generasi penerus belumsepenuhnya memuaskan bila dilihat dari segi akhlak, moral, dan jati diri bangsadalam kemajemukan budaya bangsa.

Kondisi tersebut menyebabkan sebagian masyarakat menjadi pesimisterhadap sekolah. Ada anggapan bahwa pendidikan tidak lagi mampumenciptakan mobilitas sosial mereka secara vertikal, karena sekolah tidakmenjanjikan pekerjaan yang layak. Sekolah kurang menjamin masa depan anakyang lebih baik. Perubahan paradigma baru pendidikan kepada mutu (qualityoriented) merupakan salah satu strategi untuk mencapai pembinaan keunggulanpribadi anak.Bangsa Indonesia saat ini mulai menyadari berbagai kelemahan masa lalu. Kinitengah disiapkan upaya reformasi pendidikan nasional untuk mengubah kinerjapelaksana pendidikan selama ini. Sehingga perlu memperbaiki kerusakan, kejahatan,korupsi atau kerusakan akhlak dari praktik pengelolaan pendidikan nasional.Kesalahan kebijakan pendidikan di masa lalu perlu segera diperbaiki dan diubahdengan pengelolaan yang lebih baik. Otonomi pendidikan merupakan salah satubentuk reformasi yang perlu dijalankan dengan baik.

Terwujudnya pendidikan yang bermutu membutuhkan upaya yang terus menerus untuk selalu meningkatkan pendidikan. Pada dasarnya terdapat berbagai faktor yang mempengaruhi keberhasilan pendidikan antara lain: guru, siswa, sarana dan prasarana, lingkungan pendidikan, kurikulum. Dari beberapa faktor tersebut, guru dalam kegiatan proses pembelajaran di sekolah menempati kedudukan yang sangat penting dan tanpa mengabaikan faktor penunjang yang lain, guru sebagai subyek pendidikan sangat menentukan keberhasilan pendidikan itu sendiri. Studi yang dilakukan Heyneman \& Loxley (Nasution, 2006:48) pada tahun 1983 di 29 negara menemukan bahwa di antara berbagai masukan (input) yang menentukan mutu pendidikan (yang ditunjukkan oleh prestasi belajar siswa) sepertiganya ditentukan oleh guru.

Hampir semua bangsa di dunia ini selalu mengembangkan kebijakan yang mendorong keberadaan guru yang bermutu. Salah satu kebijakan yang dikembangkan oleh pemerintah di ban yak negara adalah kebijakan intervensi langsung menuju peningkatan mutu dan memberikan jaminan dan kesejahteraan hidup guru yang memadai. Beberapa negara yang mengembangkan kebijakan ini bisa disebut antara lain Singapore, Korea Selatan, Jepang, dan Amerika Serikat. Negaranegara tersebut berupaya meningkatkan mutu guru dengan mengembangkan kebijakan yang langsung mempengaruhi mutu dengan melaksanakan sertifrkasi guru. 
Guru yang sudah ada harus mengikuti uji kompetensi untuk sertifikat profesi guru.

Kepala Sekolah merupakan salah satu komponen pendidikan yang paling berperan dalam meningkatkan kualitas pendidikan. Seperti diungkapkan Supriadi (1998:346) bahwa: "Erat hubungannya antara mutu Top Management dengan berbagai aspek kehidupan sekolah seperti disiplin sekolah, iklim budaya sekolah, dan menurunnya perilaku nakal peserta didik". Dalam pada itu, Kepala Sekolah, bertanggung-jawab atas manajemen pendidikan secara messo, yang secara langsung berkaitan dengan pengelolaan man, material, machine, money, dan proses pembelajaran di sekolah.

Apa yang diungkapkan di atas menjadi lebih penting sejalan dengan semakin kompleksnya tuntutan tugas Kepala Sekolah, yang menghendaki dukungan kinerja yang semakin efektif dan efisien. Disamping itu, perkembangan ilmu pengetahuan, teknologi, seni, dan budaya yang diterapkan dalam pendidikan di sekolah juga cenderung bergerak maju semakin pesat, sehingga menuntut penguasaan secara profesional. Menyadari hal tersebut, setiap Kepala Sekolah dihadapkan pada tantangan untuk melaksanakan pengembangan pendidikan secara terarah, berencana, dan berkesinambungan untuk meningkatkan kualitas pendidikan.

Sistem kompetisi tersebut akan mendorong sekolah untuk terus meningkatkan diri, sedangkan penghargaan akan dapat memberikan motivasi dan meningkatkan kepercayaan diri setiap personel sekolah, khususnya siswa. Apa yang diungkapkan di atas menjadi lebih penting sejalan dengan semakin kompleksnya tuntutan tugas Kepala Sekolah, yang menghendaki dukungan kinerja yang semakin efektif dan efisien. Disamping itu, perkembangan ilmu pengetahuan, teknologi, seni, dan budaya yang diterapkan dalam pendidikan di sekolah juga cenderung bergerak maju semakin pesat, sehingga menuntut penguasaan secara profesional.

Berdasarkan hasil studi pendahuluan melalui observasi dan studi dokumentasi, di bawah ini disajikan hasil Penilaian Kinerja Guru di dua sekolah yang diteliti pada tahun 2017, sebagai berikut:

Tabel 1. Hasil Penilaian Kinerja Guru

\begin{tabular}{|c|c|c|}
\hline No & Nama Sekolah & Nilai Rata-Rata PKG \\
\hline 1 & SMAN 2 Ciamis & 81,25 \\
\hline 2 & SMAN 3 Ciamis & 82,14 \\
\hline & Rata-Rata & $\mathbf{8 1 , 6 9}$ \\
\hline
\end{tabular}

Sumber: Dinas Pendidikan Kabupaten Ciamis, 2018

Berdasarkan tabel 1.1 dapat dijelaskan bahwa hasil kinerja guru jika dilihat dari nilai yang diperoleh berada pada kriteria baik yaitu interval $80-90$, namun demikian nilai kerja guru yang diperoleh belum mencapai hasil yang optimal atau berada di atas nilai 90. Untuk itu diperlukan peningkatan kinerja guru yang lebih optimal dalam upaya peningkatan mutu pendidikan, karena peran guru merupakan kunci utama dalam meningkatkan prestasi belajar siswa dan mutu lulusan. Berdasarkan uraian latar belakang penelitian, maka judul penelitian adalah: "Efektivitas Kepemimpinan Kepala Sekolah dalam Meningkatkan Kinerja Guru (Studi Kasus di SMAN 2 dan SMAN 3 Ciamis).”

\section{METODOLOGI}

Penelitian ini menggunakan metode deskriptif yaitu metode penelitian yang berusaha menggambarkan dan menginterprestasi obyek sesuai dengan apa adanya. Adapun pendekatan penelitian ini adalah pendekatan kualitatif.Objek pada penelitian ini adalah kepemimpinan kepala sekolah dan kinerja guru.Untuk memperoleh data penelitian, penulis menggunakan observasi, wawancara, studi dokumentasi. 


\section{HASIL DAN PEMBAHASAN}

\subsection{Kepemimpinan Kepala Sekolah Ditinjau Dari Kompetensi Kepribadian Dalam Meningkatkan Kinerja Guru}

Kepemimpinan kepala sekolah ditinjau dari kompetensi kepribadian melalui aspek berakhlak mulia, memiliki integritas kepribadian, memiliki keinginan yang kuat, bersikap terbuka, mengendalikan diri, dan memiliki bakat serta minat sebagai pemimpin pada umumnya berkriteria efektif sehingga dapat meningkatkan kinerja guru.Hal ini sejalan dengan penelitian yang dilakukan oleh Uray Iskandar (2013) yang berjudul "Kepemimpinan Kepala Sekolah dalam Peningkatan Kinerja Guru." Hasil penelitian menunjukkan bahwa mendeskripsikan dalam proses pembelajaran guru dipandang memiliki peran penting terutama dalam membantu peserta didik. Kinerja Guru dapat dilihat dan diukur berdasarkan spesifikasi dan kriteria kompetensi yang harus dimiliki oleh setiap guru dapat ditampilkan melalui penguasaan kompetensi pedagogik, profesional, kepribadian dan sosial. Mengingat kepemimpinan dan motivasi kerja kepala sekolah terhadap kinerja guru memberikan suatu korelasi.

Begitu pula hasil wawancara dengan ketua komite SMAN 2 Ciamis pada tanggal 5 September 2016 yang mengemukakan bahwa:Kepala sekolah memiliki rasa keingintahuan yang tinggi karena hal itu sangat penting, pengetahuan terhadap berbagai macam teori yang berkaitan dengan dunia pendidikan khususnya kompetensi kepribadian seorang kepala sekolah untuk untuk pelaksanaan suatu tugas sekolah sangat penting dimiliki oleh kepala sekolah.

Keunggulan dari penelitian ini dapat dilihat dari kepemimpinan kepala sekolah ditinjau dari kompetensi kepribadian melalui aspek berakhlak mulia, memiliki integritas kepribadian, memiliki keinginan yang kuat, bersikap terbuka, mengendalikan diri, dan memiliki bakat serta minat sebagai pemimpin pada umumnya berkriteria efektif adapun kelemahannya ada beberapa aspek yang perlu ditingkatkan antara lain:kepala sekolah menjadi tauladan dan figur bagi warga sekolah, baik dalam bersikap maupun bertutur kata melalui model 5 s yaitu senyum, salam, sapa, sopan, dan santun.

Kepala sekolah harus tampil sebagai koordinator dari sejumlah orang yang mewakili berbagai kelompok yang berbeda di dalam masyarakat sekolah dan secara profesional harus terlibat dalam setiap proses perubahan di sekolah. Ada empat hal yang terkait dengan prinsip-prinsip pengelolaan mutu sekolah sebagaimana dikemukakan Komariah (2005:76), yaitu: (1) perhatian harus ditekankan kepada proses dengan terus menerus menitikberatkan peningkatan mutu; (2) mutu harus ditentukan oleh pengguna jasa sekolah; (3) prestasi harus diperoleh melalui pemahaman visi bukan dengan pemaksaan aturan; (4) sekolah harus menghasilkan siswa yang memiliki ilmu pengetahuan, keterampilan, sikap arif bijaksana, karakter, dan memiliki kematangan emosional.

Sistem kompetisi tersebut akan mendorong sekolah untuk terus meningkatkan diri, sedangkan penghargaan akan dapat memberikan motivasi dan meningkatkan kepercayaan diri setiap personel sekolah, khususnya siswa. Apa yang diungkapkan di atas menjadi lebih penting sejalan dengan semakin kompleksnya tuntutan tugas Kepala Sekolah, yang menghendaki dukungan kinerja yang semakin efektif dan efisien. Disamping itu, perkembangan ilmu pengetahuan, teknologi, seni, dan budaya yang diterapkan dalam pendidikan di sekolah juga cenderung bergerak maju semakin pesat, sehingga menuntut 
penguasaan secara profesional. Menyadari hal tersebut, setiap Kepala Sekolah dihadapkan pada tantangan untuk melaksanakan pengembangan pendidikan secara terarah, berencana, dan berkesinambungan untuk meningkatkan kualitas pendidikan.

\subsection{Kepemimpinan Kepala Sekolah Ditinjau Dari Kompetensi Manajerial Dalam Meningkatkan Kinerja Guru}

Kepemimpinan kepala sekolah ditinjau dari kompetensi manajerial melalui aspek menyusun perencanaan sekolah, mengembangkan organisasi, memimpin sekolah, mengelola perubahan, menciptakan budaya sekolah, mengelola guru dan staf, mengelola sarana-prasarana, mengelola hubungan sekolah dan masayarakat, mengelola peserta didik, mengelola pengembangan kurikulum, mengelola keuangan, mengelola ketatausahaan, mengelola unit layanan khusus, mengelola sistem informas, memanfaatkan kemajuan teknologi informasi, dan melakukan monitoring serta evaluasi pada umumnya berada pada kriteria efektif sehingga dapat meningkatkan kinerja guru.

Hal ini sejalan dengan penelitian yang dilakukan Neneng Kurniawati (2014) dengan judul "Studi tentang Kepemimpinan dan Kemampuan Manajerial Kepala Sekolah dalam Mewujudkan Prestasi Sekolah di SMK Negeri Kota Tasikmalaya." Hasil penelitian menunjukkan bahwa:Kemampuan mamanjerial kepala sekolah di SMK Negeri Kota Tasikmalaya pada umumnya berada pada kriteria mampu hal ini dapat dilihat dari dalam menjalankan tugas sebagai pemimpin di sekolah yang berkaitan dengan perencanaan program sekolah, pengorganisasian, pengarahan/pergerakan, dan pengawasan program sekolah.Keunggulan dari penelitian ini dapat dilihat dari kepemimpinan kepala sekolah ditinjau dari kompetensi manajerial melalui aspek menyusun perencanaan sekolah, mengembangkan organisasi, memimpin sekolah, mengelola perubahan, menciptakan budaya sekolah, mengelola guru dan staf, mengelola sarana-prasarana, mengelola hubungan sekolah dan masayarakat, mengelola peserta didik, mengelola pengembangan kurikulum, mengelola keuangan, mengelola ketatausahaan, mengelola unit layanan khusus, mengelola sistem informas, memanfaatkan kemajuan teknologi informasi, dan melakukan monitoring serta evaluasi pada umumnya berada pada kriteria efektif sehingga dapat meningkatkan kinerja guru. Adapun kelemahannya ada beberapa aspek yang perlu ditingkatkan antara lain: kepala sekolah melaksanakan fungsi-fungsi manajemen dalam mengelola sekolah yang dipimpinnya menuju organisasi, pembelajar yang efektif serta selalu memanfaatkan kemajuan teknologi informasi.

Dalam rangka melakukan peran dan fungsinya sebagai manajer, kepala sekolah harus memiliki strategi yang tepat untuk memberdayakan tenaga kependidikan melalui kerjasama , memberi kesempatan kepada para tenaga kependidikan untuk meningkatkan profesinya, dan mendorong keterlibatan seluruh tenaga kependidikan. Menurut Mulyasa (2005:106) "Kepala sekolah harus memiliki kemampuan dalam melaksanakan tugas yang diwujudkan dalam kemampuan menyusun program sekolah, organisasi personalia, memberdayakan tenaga kependidikan, dan mendayagunakan sumber daya sekolah secara optimal".

Kemampuan menyusun program sekolah diwujudkan dalam (1)pengembangan program jangka panjang yang dituangkan dalam kurun waktu lebih dari lima tahun; (2) pengembangan program jangka menengah dalam kurun waktu tiga sampai lima tahun; pengembangan program jangka pendek atau program tahunan, termasuk 
penganggaran rencana anggaran pendapatan belanja sekolah (RAPBS). Kemampuan menyusun organisasi personalia sekolah diwujudkan dalam pengembangan sususunan personalia sekolah ; pengembangan susunan personalia pendukung, seperti pengelola laboratorium, perpustakaan, dan pusat sumber belajar. Kemampuan memberdayakan tenaga kependidikan di sekolah diwujudkan dalam pemberian arahan secara dinamis, pengkoordinasian tenaga kependidikandalam melaksanakan tugas, pemberian hadiah bagi mereka yang berprestasi, dan pemberian hukuman bagi yang kurang disiplin dalam melaksanakan tugas. Kemampuan mendayagunakan sumber daya sekolah, diwujudkan dalam pendayagunaan serta perawatan sarana dan prasarana sekolah, pencatatan berbagai kerja tenaga kependidikan dan pengembangan.

\subsection{Kepemimpinan Kepala Sekolah Ditinjau Dari Kompetensi Kewirausahaan Dalam Meningkatkan Kinerja Guru}

Kepemimpinan kepala sekolah ditinjau dari kompetensi kewirausahaan melalui aspek menciptakan inovasi untuk pengembangan sekolah, bekerja keras untuk mencapai keberhasilan sekolah, memiliki motivasi yang kuat untuk sukses, pantang menyerah dan selalu mencari solusi terbaik, serta memiliki naluri kewirausahaan pada umumnya berada pada kriteria efektif sehingga dapat meningkatkan kinerja guru.

Keunggulan dari penelitian ini dapat dilihat dari kepemimpinan kepala sekolah ditinjau dari kompetensi kewirausahaan melalui aspek menciptakan inovasi untuk pengembangan sekolah, bekerja keras untuk mencapai keberhasilan sekolah, memiliki motivasi yang kuat untuk sukses, pantang menyerah dan selalu mencari solusi terbaik, serta memiliki naluri kewirausahaan pada umumnya berada pada kriteria efektif sehingga dapat meningkatkan kinerja guru.
Adapun kelemahannya ada beberapa aspek yang perlu ditingkatkan antara lain: kepala sekolah menciptakan inovasi yang berguna bagi pengembangan sekolah, baik inovasi dalam pembelajaran maupun inovasi dalam mengelola kegiatan produksi/jasa sebagai sumber belajar peserta didik.

Kepala sekolah sebagai pemimpin dan penanggung jawab penyelenggaraan pendidikan di sekolah terutama setelah diterapkan MBS dalam pengelolaan sekolah, harus memiliki profesionalitas yang tidak diragukan lagi demi tercapainya prestasi sekolah yang membanggakan. Kepala sekolah yang profesional harus selalu kreatif dan produktif dalam melakukan inovasi pendidikan untuk meningkatkan kualitas pendidikan. Jalal (2005: 1), berpendapat bahwa untuk meningkatkan profesionalisme kepala sekolah di institusi pendidikan, diperlukan berbagai upaya berupa:Peningkatan kreativitas kerja, motivasi kerja, kinerja, dan produktivitas kerja kepala sekolah serta pemberian berbagai jenis bentuk pelatihan, pendidikan profesional, dan berbagai kegiatan profesional lainnya kepada kepala sekolah untuk meningkatkan mutu pendidikan. Namun diperlukan juga kebijakan pemerintah dalam mengembangkan sumber daya manusia melalui profesionalisasi pendidik dan tenaga kependidikan dalam upaya meningkatkan kualitas kepala sekolah dan kualitas pendidikan.

Melalui kepala sekolah yang produktif, situasi pembelajaran dapat dilakukan secara efisien, efektif, menarik, dan menyenangkan. Hal ini disebabkan karena di tangan kepala sekolah yang kreatif lahir berbagai ide-ide kreatif dalam menggunakan metode dan strategi pembelajaran yang variatif, inovatif, dan menyenangkan bagi peserta didik karena sesuai dengan kebutuhan belajar peserta didik. Lebih jauhnya mampu 
membangkitkan prestasi sekolah yang membanggakan melalui kinerja guru.

\subsection{Kepemimpinan Kepala Sekolah Ditinjau Dari Kompetensi Supervisi Dalam Meningkatkan Kinerja Guru}

Kepemimpinan kepala sekolah ditinjau dari kompetensi supervisi melalui aspek merencanakan program supervisi akademik, melaksanakan supervisi akademik, dan menindaklanjuti hasil supervisi akademik terhadap guru pada umumnya berada pada kriteria efektif sehingga dapat meningkatkan kinerja guru.

Keunggulan dari penelitian ini dapat dilihat dari kepemimpinan kepala sekolah ditinjau dari kompetensi supervisi melalui aspek merencanakan program supervisi akademik, melaksanakan supervisi akademik, dan menindaklanjuti hasil supervisi akademik terhadap guru pada umumnya berada pada kriteria efektif sehingga dapat meningkatkan kinerja guru. Adapun kelemahannya ada beberapa aspek yang perlu ditingkatkan antara lain: kepala sekolah merencanakan, melaksanakan, dan menindaklanjuti hasil supervisi sehingga terjadi umpan balik yang positif antara kepala sekolah dan guru.

Kepala sekolah dalam melaksanakan fungsinya sebagai supervisor, mencakup kegiatan-kegiatan yang bersangkutan dalam pembangkitan semangat, kerja sama guruguru, pemenuhan alat-alat dan perlengkapan sekolah demi kelancaran pengajaran. Pengembangan dan pembinaan pengetahuan serta keterampilan guru-guru, serta kerja sama antara sekolah dan masyarakat, yang semuanya ditujukan untuk meningkatkan kualitas proses belajar mengajar.Dalam pelaksanaannya, supervisor perlu memahami fungsi-fungsi supervisi yang merupakan tugas pokok sebagai supervisor pendidikan. Fungsifungsi supervisi menurut Swearingen (Wahyudi, 2009:120) sebagai berikut: (1) Mengkoordinasi semua usaha sekolah; (2)
Melengkapi kepemimpinan sekolah; (2)

Memperluas pengalaman guru-guru; (3) Menstimulasikan usaha-usaha yang kreatif;(4) Memberikan fasilitas dan penilaian yang terus-menerus; Menganalisis situasi belajar dan mengajar; (6) Memberikan pengetahuan dan keterampilan kepada setiap anggota staf; (7) Mengintegrasikan tujuan pendidikan dan membantu meningkatkankemampuan guruguru dalam mengajar.

Praktek supervisi, kepala sekolah dan guruguru tidak diperlakukan sebagai bawahan, melainkan sebagai rekan sejawat, tata kerja yang dikembangkan adalah bekerjasama, kendatipun struktur organisasi yang birokratik tetap dihargai. Pendekatan perilaku supervisi adalah menciptakan dan menjaga keselarasan antara tujuan-tujuan kepentingan pribadi (personal needs) dan tujuan-tujuan organisasi (institusional goals) melalui kerja team dan evaluasi terhadap sasaran supervisi.

\subsection{Kepemimpinan Kepala Sekolah Ditinjau Dari Kompetensi Sosial Dalam Meningkatkan Kinerja Guru}

Kepemimpinan kepala sekolah ditinjau dari kompetensi sosial melalui aspek bekerjasama dengan pihak lain untuk kepentingan sekolah, berpartisipasi dalam kegiatan sosial kemasyarakatan, dan memiliki kepekaan sosial terhadap orang atau kelompok lain pada umumnya berada pada kriteria efektif sehingga dapat meningkatkan kinerja guru. Hal ini sejalan Dedeh Sofia Hasanah, (2010), dengan judul penelitian "Pengaruh Kompetensi Kepala Sekolah dan Kinerja Guru terhadap Kualitas Pembelajaran di SD Negeri SeKecamatan Babakan Cikao Kabupaten Purwakarta." Hasil penelitian menunjukkan bahwa: Kompetensi sosial kepala sekolah berpengaruh positif terhadap kualitas pembelajaran, ini berarti semakin meningkat kompetensi sosial kepala sekolah maka semakin meningkat kualitas pembelajaran. 
Keunggulan dari penelitian ini dapat dilihat dari kepemimpinan kepala sekolah ditinjau dari kompetensi sosial melalui aspek bekerjasama dengan pihak lain untuk kepentingan sekolah, berpartisipasi dalam kegiatan sosial kemasyarakatan, dan memiliki kepekaan sosial terhadap orang atau kelompok lain pada umumnya berada pada kriteria efektif sehingga dapat meningkatkan kinerja guru. Adapun kelemahannya ada beberapa aspek yang perlu ditingkatkan antara lain: kepala sekolah selalu melaksanakan kegiatan sosial kemasyarakatan maupun bekerjasama dengan instansi lain untuk kepentingan sekolah, misalnya melalui donor darah, bakti sosial, maupun kegiatan lain.

Keberhasilan manajemen kualitas suatu organisasi sangat ditentukan oleh budaya mutu yang dimiliki organisasi tersebut. Berbicara kualitas organisasi sekolah sangat berkaitan dengan keterampilan kepala sekolah dalam mekanisme kerja administrasi di sekolah sebagai proses sosial. Tiga keterampilan yang harus dimiliki kepala sekolah menurut Katz (1995) yang dikutif Sergiovani dkk (1987) dalam Sudarwan (2002 : 134) meliputi : (1) Keterampilan teknis (technical skill) mencakup pemahaman metode, proses, prosedur, dan teknik-teknik pendidikan; (2) Keterampilan melakukan hubunganhubungan kemanusiaan (human skill); (3) Keterampilan konseptual (conceptual skill), yaitu berkaitan dengan cara kepala sekolah memandang sekolah, keterkaitan sekolah dengan struktur di atasnya dan dengan pranata-pranata kemasyarakatan, serta program kerja sekolah secara keseluruhan.

Selain tiga keterampilan kepala sekolah dalam mekanisme kerja administrasi, kepala sekolah harus mempunyai kompetensi dalam menjalankan tugas teknis manajerial. Menurut Mintzberg (1973:12) dalam Sudarwan (2002 : 137) ada tiga kategori tugas teknis manajerial kepala sekolah, yaitu : (1) Interpersonal, yaitu kepala sekolah menjalankan fungsi sebagai figur pemimpin, dan juru runding; (2) Informational, yaitu kepala sekolah menjalankan fungsi sebagai pemantau, penyebar, dan perantara; (3) Decistional, yaitu kepala sekolah menjalankan fungsi sebagai wiraswastawan, pengalokasi sumber-sumber, dan negosiator.

Kemampuan dalam hal teori dan praktik manajemen sekolah, diperlukan kepala sekolah yang berkualitas untuk menjalankan tugas operatifnya secara profesional.

\section{KESIMPULAN}

Berdasarkan pembahasan yang telah dilakukan, maka dapat diambil beberapa kesimpulan sesuai dengan permasalahan yang diteliti, sebagai berikut:

1. Kepemimpinan kepala sekolah ditinjau dari kompetensi kepribadian melalui aspek berakhlak mulia, memiliki integritas kepribadian, memiliki keinginan yang kuat, bersikap terbuka, mengendalikan diri, dan memiliki bakat serta minat sebagai pemimpin pada umumnya berkriteria efektif sehingga dapat meningkatkan kinerja guru.

2. Kepemimpinan kepala sekolah ditinjau dari kompetensi manajerial melalui aspek menyusun perencanaan sekolah, mengembangkan organisasi, memimpin sekolah, mengelola perubahan, menciptakan budaya sekolah, mengelola guru dan staf, mengelola saranaprasarana, mengelola hubungan sekolah dan masayarakat, mengelola peserta didik, mengelola pengembangan kurikulum, mengelola keuangan, mengelola ketatausahaan, mengelola unit layanan khusus, mengelola sistem informas, memanfaatkan kemajuan teknologi informasi, dan melakukan monitoring serta evaluasi pada umumnya berada pada kriteria efektif 
sehingga dapat meningkatkan kinerja guru.

3. Kepemimpinan kepala sekolah ditinjau dari kompetensi kewirausahaan melalui aspek menciptakan inovasi untuk pengembangan sekolah, bekerja keras untuk mencapai keberhasilan sekolah, memiliki motivasi yang kuat untuk sukses, pantang menyerah dan selalu mencari solusi terbaik, serta memiliki naluri kewirausahaan pada umumnya berada pada kriteria efektif sehingga dapat meningkatkan kinerja guru.

4. Kepemimpinan kepala sekolah ditinjau dari kompetensi supervisi melalui aspek merencanakan program supervisi akademik, melaksanakan supervisi akademik, dan menindaklanjuti hasil supervisi akademik terhadap guru pada umumnya berada pada kriteria efektif sehingga dapat meningkatkan kinerja guru.

5. Kepemimpinan kepala sekolah ditinjau dari kompetensi sosial melalui aspek bekerjasama dengan pihak lain untuk kepentingan sekolah, berpartisipasi dalam kegiatan sosial kemasyarakatan, dan memiliki kepekaan sosial terhadap orang atau kelompok lain pada umumnya berada pada kriteria efektif sehingga dapat meningkatkan kinerja guru.

\section{DAFTAR PUSTAKA}

Akdon, 2000, Manajemen Stratejik untuk Manajemen Pendidikan, Bandung, Alfabeta.

Depdiknas, 2006, Pelaksanaan Standar Isi dan Kompetensi Lulusan, Jakarta: Permendiknas No. 24 Tahun 2006.

Jalal, Fasli, 2007, Pendidikan yang Bermutu, tersedia pada http://kemendikbud.go.id// (akses tanggal 20 Nopember 2017)
Moleong, Lexy, J., 2006, Metodologi Penelitian Kualitatif. Bandung: Remaja Karya.

Mulyasa, E, 2005, Menjadi Guru Profesional. Bandung. Remaja Rosdakarya.

Nasution, Muhamad, 2006, Manajemen Mutu Terpadu, Jakarta: Bumi Aksara

Peraturan Menteri Pendidikan Nasional Nomor 13 Tahun 2007 tentang Kompetensi Kepala Sekolah

Permendiknas No. 13 Tahun 2007 Tentang Standar Kepala Sekolah

Permendiknas No. 16 Tahun 2007 Tentang Kompetensi Guru

Sedarmayanti, 2011, Manajemen Sumber Daya Manusia: Reformasi Birokrasi dan Manajemen Pegawai Negeri Sipil. Bandung: Refika Aditama.

Sudarwan Danim, 2002, Inovasi Pendidikan, Bandung, Pustaka Setia

Supriadi, Dedi, 1998., Teori Hierarki Kebutuhan maslow; tersedia : http// organisasi.org/teorihierarki Maslaw. (akses tanggal 20 Nopember 2017)

Supriadi, Dedi, 1998., Teori Hierarki Kebutuhan maslow; tersedia : http// organisasi.org/teorihierarki Maslaw. (akses tanggal 20 Nopember 2017)

Undang-Undang No. 14 Tahun 2005 Tentang Guru dan Dosen

Undang-Undang No. 20 Tahun 2003 Tentang Sistem Pendidikan Nasional

Iskandar, U. (2013). Kepemimpinan kepala sekolah dalam peningkatan kinerja guru. Jurnal Visi Ilmu Pendidikan, 10(1).

Wahjosumidjio. 1999, Implementasi Manajemen Mutu Terpadu (Total Quality Management) di Sekolah. Tasikmalaya: Tim Sosialisasi Dewan Pendidikan Kota Tasikmalaya.

Wahyudi, 2009, Kepemimpinan Kepala Sekolah, Jakarta: Galia Indonesia 